\title{
Correction to: Clinical epidemiology of infectious disease among patients with chronic kidney disease
}

\author{
Junichi Ishigami ${ }^{1} \mathbb{D} \cdot$ Kunihiro Matsushita ${ }^{1}$
}

Published online: 2 March 2019

(c) The Author(s) 2019

\section{Correction to: Clinical and Experimental Nephrology https://doi.org/10.1007/s10157-018-1641-8}

The article "Clinical epidemiology of infectious disease among patients with chronic kidney disease", written by Junichi Ishigami and Kunihiro Matsushita, was originally published electronically on the publisher's internet portal (currently SpringerLink) on 3rd September 2018 without open access. With the author(s)' decision to opt for Open Choice the copyright of the article changed on 19th February 2019 to (C) The Author(s) 2019 and the article is forthwith distributed under the terms of the Creative Commons Attribution 4.0 International License (http://creativeco mmons.org/licenses/by/4.0/), which permits use, duplication, adaptation, distribution and reproduction in any medium or format, as long as you give appropriate credit to the original author(s) and the source, provide a link to the Creative Commons license and indicate if changes were made.

The original article has been corrected.

The original article can be found online at https://doi.org/10.1007/ s10157-018-1641-8.

Junichi Ishigami jishiga1@jhu.edu

1 Department of Epidemiology, Welch Center for Prevention, Epidemiology, and Clinical Research, Johns Hopkins

Bloomberg School of Public Health, 2024 E. Monument St., Suite 2-600, Baltimore, MD 21287, USA
Open Access This article is distributed under the terms of the Creative Commons Attribution 4.0 International License (http://creativeco mmons.org/licenses/by/4.0/), which permits unrestricted use, distribution, and reproduction in any medium, provided you give appropriate credit to the original author(s) and the source, provide a link to the Creative Commons license, and indicate if changes were made.

Publisher's Note Springer Nature remains neutral with regard to jurisdictional claims in published maps and institutional affiliations. 